\title{
Relationship Between Inflation and Unemployment: Testing Philips Curve Hypotheses and Investigating the Causes of Inflation and Unemployment in Nigeria
}

\section{Samuel Ugochukwu Daniel ${ }^{1}$, Victoria Chidinma Israel ${ }^{2}$, Chibuzor Benjamin Chidubem ${ }^{3}$, Joel Quansah ${ }^{4}$}

${ }^{1}$ Ebonyi State University

PMB 053, Abakaliki, Nigeria

${ }^{2}$ Michael Okpara University of Agriculture, Umudike

PMB 7267, Umuahia Umudike, Abia State, Nigeria

${ }^{3}$ University of Uyo

Ikpa Road, PMB 1017, Akwa Ibom, Ibom State, Nigeria

${ }^{4}$ Regent University College of Science and Technology

1 Regent University Avenue, McCarthy, Mendskrom, Accra-Winneba Road, Ghana

\section{DOI: $10.22178 /$ pos. $74-13$}

JEL Classification: E31

Received 21.08.2021

Accepted 25.09.2021

Published online 30.09.2021

Corresponding Author:

Samuel Ugochukwu Daniel

samuelug01995@gmail.com

(c) 2021 The Authors. This

article is licensed under a

Creative Commons Attribution

4.0 License @) (1)

\begin{abstract}
The attainment of full employment and price stability are one of the most widely used measures of economic health. Inflation and unemployment are an integral part of an economy; however, there is a need to balance both such that neither inflation nor unemployment is too high. The persistent rise in inflation and unemployment rates has called for the need to investigate the relevance of Philip's postulation of a trade-off between inflation and unemployment in Nigeria. In addition to the interdependency or independence of these variables, there is also a need to access factors that may contribute to the increasing inflation and unemployment rates in Nigeria. These will enable policymakers to formulate policies that affect inflation and unemployment and pay attention to other variables that may directly or indirectly affect inflation and unemployment. Therefore, the study aims to test the validity of Philip's curve hypotheses and examine possible causes of inflation and unemployment in Nigeria. The study used secondary data sourced from the Central Bank of Nigeria and the World Bank. Vector Autoregressive and Error Correction methods were adopted for the analysis. The study revealed that there is no significant relationship between inflation and unemployment in Nigeria. Inefficiencies from the government's side and insufficient domestic investment were observed to be the possible causes of unemployment, whereas; exchange rate depreciation and money supply are blamed for the rising price levels in Nigeria. The study concludes that the problems of inflation and unemployment arise from inefficiencies in both monetary and fiscal policies. Efficient use of fiscal and monetary policies was recommended to raise employment and output in all sectors to meet the steaming local demand and export. Also, the full implementation of economic diversification policies is recommended. Furthermore, the study recommends increasing government spending on social infrastructure and incentives to firms to promote investment in Nigeria. These will have an overall effect of increasing output, reducing unemployment and achieving non-inflationary growth in Nigeria.
\end{abstract}

Keywords: inflation; unemployment; Philip's Curve; monetary and policies; economic diversification.

\section{INTRODUCTION}

The primary goals of macroeconomic policies are to attain economic stability in various sectors of the economy. Economies of the world aim to achieve increased economic growth and development accompanied by the unemployment rate with non-accelerating inflation, known as the natural unemployment rate. The world over, 
there is the need to maintain a balance in both domestic and foreign sectors and achieve sustained economic growth and a competitive exchange rate. It is often believed that a single-digit rate of inflation and an unemployment rate of about five per cent would ensure macroeconomic stability in an economy, all things being equal [27].

The maintenance of price stability and low unemployment rate took another dimension. It thus became a burning issue of thought after the work of J. W. Philips in 1958 on the relationship between money wage and employment [11]. After analyzing data for over a hundred years, Philips found out that there is a certain level of unemployment between 6 and $7 \%$ in which the wage level is constant, and its increment is zero. Therefore, when unemployment falls below this natural level, there would be a rapid increase in wages and vice versa [3]. Therefore, Philip's postulations are represented using the "Philip's Curve".

Before Philip's postulation in 1958, inflation and unemployment were treated differently. For instance, the monetarist and the classical school viewed inflation as an excessive money supply relative to output. Inflation to them was created when the money supply is increased at complete employment levels of output. The monetarist school cantered their view of unemployment on Milton Friedman's permanent income hypothesis. They believed that a decline in current receipts and employment only affects output to the anticipated income declines. The classical school saw unemployment as abnormal. To them, overproduction and unemployment are temporary as the market adjusts to full employment. Each school of thought offered its policy solutions. However, no attempts were made to explain the behaviours of inflation and unemployment together. Authors [25], on the other hand, viewed inflation as being caused by an excess of expenditure over income at the whole employment level. When output does not adjust to an increase in consumer expenditures, it results in inflation. This is because, as more money chases few goods, consumers tend to bid prices up. Keynesians regard inflation to be an aftermath of the money supply that keeps on increasing [1]. Keynes attributed unemployment to a fall in effective demand. Unemployment has been viewed as one of the serious impediments to social progress. Unemployment represents a waste of a nation's workforce and a loss of welfare, leading to lower output, lower-income and well-being [29].
Since a high unemployment rate represents output loss to the economy, achieving a minimal rate (if possible, the natural rate) of unemployment is a critical macroeconomic objective of every nation irrespective of development. Author [26] pointed out that unemployment is a global problem that poses a severe challenge to developed and developing countries. According to Keynes, increasing government spending can improve employment by boosting aggregate demand (consumption and investment).

Unemployment in Nigeria is not a recent phenomenon, as noted by [27]. However, since the early eighties, unemployment has assumed an alarming dimension as millions of non-disabled persons are willing to accept jobs at the prevailing wage rate but cannot find a job. Author [14] cited by [27] maintained that unemployment had been regarded as one of the most challenging economic problems facing Nigerian Policymakers.

Inflation, on the other hand, has been a significant problem in Nigeria. Likewise, rising inflation levels have become more prevalent in most developing countries than any other macroeconomic concept. Households, especially low-income earners, complain of the actual value of their income being depleted as they can no longer afford to buy the quantities they used to buy before. The coronavirus disease of 2019 has further worsened the unemployment and inflation rates in Nigeria. Finding a balance between unemployment and inflation has become a critical economic goal that every nation seeks to achieve. As noted by [27], attaining stability in inflation and unemployment rates is of great advantage for any economy to achieve sustainable growth and development. Economic growth, when considered in real terms, will be worthless without stability. A similar argument [22] confirmed that inflation and unemployment are critical economic growth and development factors.

Inflation and unemployment, an integral part of every market economy, come with some socioeconomic consequences for the population of the countries in which these processes occur. However, the big question is, "does inflation spring unemployment or are they independent of each other?" this question becomes very important due to the observed pattern in inflation and unemployment trends, especially in developing countries such as Nigeria. 
Empirical studies carried out in recent years have, in one way or the other, invalidated the trade-off between inflation and unemployment, as postulated by Phillips. For instance, [21, 30] found a positive relationship to exist between inflation and unemployment, while [19] cited by [11] found a significant relationship between inflation and unemployment rates in Nigeria. Both high inflation rates and high unemployment rates have been observed to coexist, especially in developing countries (Nigeria inclusive), reflecting a situation known as stagflation. Stagflation is a situation whereby low productivity or declining GDP coexists with inflation. In other words, the economy is stagnant, but inflation is rising.

In Nigeria, unemployment has continued to surge upwards at an alarming rate. This surge in the unemployment rate has been consistent with the rise in inflation rates. For instance, in the second quarter of 2021, the inflation rate in Nigeria rose to $17.75 \%$, with the unemployment rate at $33.3 \%$; the coexistence of high inflation and unemployment rates invalidates Philip's hypothesis. Author [33] cited by [17] noted that the Nigerian economy is battling shocking inflation alongside a severe recession as the unemployment rate rose astronomically. The author concluded that the Nigerian economy is at a crossroad. However, authors like as $[9,2,20,6]$ have a contrary opinion as their findings validated the existence of Philip's curve in Nigeria. The conflict between empirical findings and reality has called for further investigation on the subject matter.

This research work's primary interest is to further investigate the validity of Philip's curve in Nigeria by extending the analysis periods to 2020. Also, the research seeks to identify the possible causes of inflation and unemployment in Nigeria.

\section{Literature review}

Conceptual Literature. There have been various definitions for the concept of unemployment. Authors [5] viewed unemployment as the difference between labour at the current wage rate and working conditions and the amount hired at these levels. The classical economists defined unemployment as excess supply of labour over demand caused by adjustment in real weal. Authors [15] noted that unemployment is a situation in which people who are willing to work at the prevailing wage rate cannot find jobs. In other words, no matter how unemployment is defined, the underlying philosophy is that those who are willing to work are true not working [15]. According to [4], unemployment is conceptualized as when workers are involuntarily out of work. The rate of the Unemployment rate is calculated by taking the number of unemployed people and dividing them by the total labour force.

Like [13] pus it "inflation is always and everywhere a monetary phenomenon and can be produced only by a more rapid increase in the quantity of money than output". It could also be seen to result from pressure-demand given a constant supply which then pushes prices up. Finally, authors [4] saw inflation as a rising general price level of a broad spectrum of goods and services over a given period. Inflation is commonly measured using the consumer price index (CPI) or the GDP deflator.

History and Trend of Unemployment and Inflation in Nigeria. According to available data, the problem of unemployment followed the recession of the 1980s when crude oil prices fell below $\$ 10$ per barrel. According to [26], the economy's downturn made the government implement restrictive policies such as exports, causing most manufacturing enterprises to be importdependent, making those firms operate belowinstalled capacity. The authors noted that as a consequence, it led to the closedown of many industries, while the few that survived were forced to make redundant a large proportion of their workforce. The government at that time was also finding it increasingly difficult to fund its budget. As a result, SAP was introduced in 1986 to reduce the fiscal imbalance experienced in the country. Among the objectives of SAP was to achieve economic diversification, promote noninflationary economic growth, reduce inflation by 9\% yearly and adopt measures to expand the economy's supply base and encourage production. These were supposed to return the Nigerian economy to the path of sustainable prosperity. According to the Central Bank of Nigeria, Nigeria's unemployment rate pre-SAP era was $4.3 \%$ in 1970 . However, this increased to $6.4 \%$ in 1980. A significant policy implication of the SAP policy was the depreciation of the Nigerian Naira. The depreciation of the naira made importation costlier; thus, making it more expensive for domestic firms to import materials needed in the production process. Following the SAP policy and the depreciation of the naira, inflation took a spiral. The rising inflation resulted in a decline in the 
real wage. A fall in real wage implies a fall in the purchasing power of the worker. Aggregate demand was affected by the declining actual income levels because people could no longer buy plenty like they previously did. As a result of these, industries started to accumulate unintended inventories. Manufacturing firms started to rationalize their market prices; the manufacturing sector became weak. Irrespective of this, there continued to be an inflow of graduates produced by educational institutions. Since industries were already suffering from shock, these graduates could not be absorbed. These resulted in unemployment. Thus, the government's objective of achieving price stability and full employment failed [34, 29].

The middle 1970s saw the oil boom in the economy coupled with high inflation rates; there were no practical efforts to reduce the inflation rate. Instead, Udoji's award was an inflationary policy that unnecessarily left money in civil servants' pockets [27]. In a bid to loosen the fiscal policy during the SAP era, inflation was worsened. The inflation rate jumped from $16 \%$ in 1987 to $55 \%$ in 1988 before dropping to $7 \%$ in 1990 and then going up to $50 \%$ in 1992.

Though the introduction of SAP sounded plausible, it left the macroeconomic environment highly destabilizing [27]. The idea of exchange rate devaluation made the policy target of reducing inflation impossible. This was because policies to increase productivity and reduce import dependencies were not fully implemented. Firms continued to import raw materials and equipment even at a high cost, reflected in production and price.

Current data shows that unemployment and inflation rates in Nigeria are double-digit. Unemployment and inflation rates averaged at 5.70\% and $25.61 \%$ from 1981 to 2000, respectively. Nigeria's unemployment as of 2001 was $13.6 \%$ but rose to $14.8 \%$ in 2003; it was not until 2009 that the rate rose to $19.7 \%$. It continued an upward trend to $21.4 \%$ in $2010,27.4 \%$ in 2012 before declining to $23.1 \%$ in 2017. By 2018, unemployment rate further declined to $22.6 \%$ but rose to $23.1 \%$ in 2019 and $33.3 \%$ in 2020 [8].

On the other hand, the inflation rate in Nigeria was $20.81 \%$ in 1981 ; by 1985 , it had fallen to $7.4 \%$, and by 1995 , it had risen to as high as $72.8 \%$ but declined to $10 \%$ in 1998. In 2001 and 2005 , the inflation rate was $18.9 \%$ and $17.9 \%$, respectively. It fell to $5.4 \%$ in 2007 , and within about two years, it rose to $13.72 \%$. In 2014 it stood at $8 \%$, it moved to $9 \%$ in 2015 , before having a sharp rise to $15.7 \%$ in 2016 and $16.3 \%$ in 2017. In 2018 and 2019, inflation rates were $11.03 \%$ and $11.4 \%$, respectively [8]. According to [8] inflation rate rose to $18.12 \%, 17.93 \%$ and 17.75\% in April, May and June 2021.

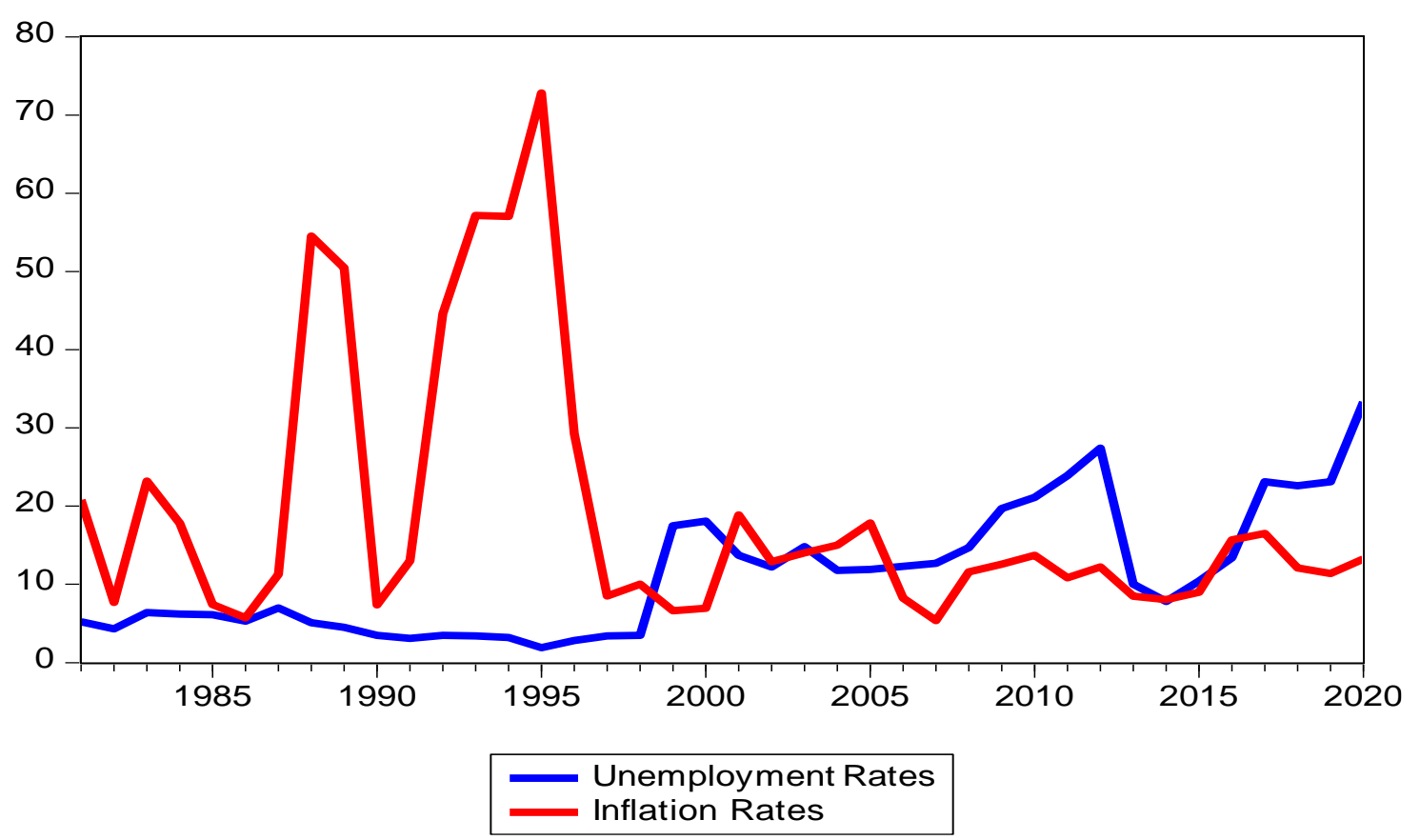

Figure 1 - Inflation and Unemployment Trend, \% 
On looking at the above graph, one can easily say that Philip's curve has existed in most periods in Nigeria. Similarly, there are other periods where inflation and unemployment coincided while periods where the variables went in the same direction. However, from 2013, it is seen that both variables moved in the same direction. Based on these multiple-insight scenarios and the effects of inflation and unemployment in the country, it is, therefore, a great motivation of this research work to empirically unravel the relationship between these two macroeconomic variables in $\mathrm{Ni}$ geria. Therefore, it is essential to look at some theories on both concepts briefly.

Theoretical Review. Several theories have long been developed to explain the relationship between inflation and unemployment. Some of these theories explain inflation and unemployment separately, while others, like the Philips curve, harmonize both concepts. Below is a review of some of these theories.

Theories of Unemployment. With the assumption of full employment, the classical theorist considered unemployment abnormal and impossible. They assumed that the market could be cleared with the interaction of demand and supply, and as such, there is neither overproduction nor unemployment. In cases whereby the abnormalities of overproduction or unemployment exist, it exists only for a short while. Basing their argument on a flexible wage system, they claim that automatic forces in the economic system tend to maintain full employment and produce output at that level. The assumptions and postulations of this group of theorists were greatly criticized, especially after the great depression of the 1920s. A significant critic to these theorists is John Maynard Keynes. Observing the inability of the market to achieve equilibrium, Keynes came up to disapprove the classical ideology starting with the idea that the economy was always at the whole employment level of output. To Keynes, underemployment rather than full employment existed. In his book titled General Theory on Employment, Interest and Money, Keynes observed that people and businesses hoard cash and avoid investment during a recession. He also observed the possibility of savings, which makes it possible that goods produced may not be completely cleared, thus questioning the classical school's belief. According to Keynesian economics, employment depends on effective demand. Effective demand results in output, output creates income, and income provides employment - Keynesian theory viewed employment as a function of income. Also, effective demand depends on the aggregate supply and demand function. Keynes paid greater attention to the demand side of the economy; he stated that supply was stable. It was the increase in aggregate demand that could solve the problems of depression and unemployment. According to him, employment can be increased by increasing consumption and/or investment, forming aggregate demand. Keynes advocated for government intervention to solve the problems of unemployment. Authors $[16,18]$ support the Keynesian theory that increases in employment rate, capital stock and technological change are primarily endogenous. Hence, the growth of employment is dependent on demand and that the primary influencer of long-term growth of output also influences the growth of employment.

Theories of Inflation. One of the earliest attempts to explain inflation was the quantity theory of money developed by American Economist Irving Fisher in 1911. The theory assumed output to be constant, hence, implying a full-employment level of output. Furthermore, the velocity of money, which expresses the number of times money changes hand, is also assumed to be constant. Given these assumptions, the theory holds that money supply had a direct influence on price levels. Therefore, increasing the money supply will increase prices by the same proportion as the money supply. The mathematical expression is given as:

$$
M V=P Q,
$$

where $M$ represents money supply or money stock; $V$ is the velocity of money in circulation; $P$ is the average price level; $Q$ represents output.

$$
\mathrm{P}=\frac{M V}{Q}
$$

This shows a direct link between price and money supply, given a constant $V$.

Neo-classical economists later built on the model. For example, the Cambridge school argues that inflation is caused by an increase in the demand for money. Their model is given as:

$M D=K P Q$, 
where $M D$ presents money demand; $P$ is the general price level; $Q$ is actual output; the constant proportion of total income that people want to hold in the form of money is presented by $K$.

$$
\mathrm{P}=\frac{M D}{K Q},
$$

where $K$ and $Q$ are assumed constant.

The equation implies that the general price level increases in proportion to the increase in the demand for money. That is, there is a direct link between general prices and money demand given $K$ and $Q$.

However, if $K$ and $Q$ change, then the inflation rate will depend on the difference in the increase in demand for money and the sum of the rates of changes in $K$ and $Q$. Consequently, inflation will be higher with low values of $K$ and $Q$.

Arguably, this argument will be actual for $Q$ because if the output increases with the demand for money, the general price level will be relatively stable. Still, if the proportion of total income that people want to hold in the form of money increases with the demand for money, the overall effect should be more inflation.

Keynes opposed a direct or proportionality between the quantity of money and the general price level. Instead, he argues that there is an indirect or non-proportional relationship between these two variables. For example, the interest rate is an essential variable in the Keynesian money-price mechanism. The interest rate will fall when the money supply increases, stimulating investment and aggregate demand, raising output and employment without rising inflation. Arguing against the idea of full employment, Keynes stated that as long as there is unemployment in the economy, output and employment will change in the same proportion as money. Still, there will be no change in price.

The monetary economist extensively criticized the Keynesian postulations. The basis of the monetary economist advocacy is in classical theory. Professor of Chicago University Milton Friedman was the frontman of the monetary theory. Friedman examined the relationship between money supply and prices and concluded that inflation is "always and everywhere a monetary phenomenon". The monetary economist maintained the classical ideology of causality running from the left hand of the equation $(M V)$ to the right hand $(P Q)$. The monetarist saw inflation as detrimental to the economy as it creates uncertainty in the economy. They advocated for a tight hold of money supply and that it should only be increased at a constant annual rate tied to the potential growth of GDP expressed as a percentage. They argued that reducing the growth rate of the money supply can reduce inflation without a long-run increase in unemployment since the demand for labour will fall. Once price and wage inflation have adjusted to this new level of demand, unemployment will be eliminated. It is arguable how these would happen given that a reduction in money supply will cause the interest rate to rise, investment to fall, and output and employment.

Philip's Curve. The original Philips curve expressed an inverse relationship between the rate of unemployment and a wage increase. Author [33] cited by [11] noted that Philip's curve shows that a decrease in the unemployment rate (increased in employment rate) moves in reverse order with increases in the rate of inflation. Philip's idea was based on an empirical analysis of historical data from the UK. The idea behind Phillips's theory was that, if for any reason, the demand for labour were higher than the supply of labour, then the equilibrium wage rates would be expected to rise above current wage levels. When unemployment is low, the rate of wage increase is high; when the wage rate is high, labourers will be more willing to offer their services. Employers will further bid the wage rate higher with only a few unemployed people as more workers are hired. Thus, as more workers are hired, unemployment falls. Contrarily, suppose the supply of labour tends to be greater than the demand for labour (the difference being unemployment). In that case, the equilibrium wage rate will be less than the current wage and will keep falling except with resistance from the labour union. Thus, the rate of changes in wages depended on the differences between the demand and supply of labour.

Several Economists have tried to extend the original Philips curve to cover the trade-off between unemployment and changes in the price level or inflation. They assume that the resultant effect is inflation whenever the money wage increases higher than the increase in output.

Empirical Review. Many scholars have conducted an intensive study on the relationship existing 
between unemployment and the inflation rate. Such empirical studies have been conducted in both developed and developing countries. Some of those studies are reviewed below.

Author [21] investigated price expectations and the Philips curve hypothesis in the Nigerian economy. They applied the Persimonous Error Correction Model and the Johansen method of cointegration. Their result revealed the prevalence of a direct relationship between inflation and unemployment in Nigeria, thereby disproving the Philips curve hypothesis of an inverse relationship. Author [33] studied the responsiveness of unemployment to inflation in Nigeria. Their study covered a period between 1989 and 2014 . They adopted the Error Correlation Model (ECM) and the Johansen technique in their study. They found that a long-run relationship existed between inflation and unemployment. They also found that inflation hurt unemployment in Nigeria. Authors [6] employed ARDL approach in studying the nature of inflation and unemployment in Nigeria. Their study covered periods between 1977 and 2011. They found that a longrun relationship exists between inflation and unemployment in Nigeria. They also found that an inverse relationship exists between inflation and unemployment in Nigeria. Author [20] employed Vector Auto-regressive model and Impulse Response Function in investigating the Phillips curve in Nigeria and the period of existence in the presence of such existence for the periods between 1980 and 2016. Their study validates the presence of the Phillips curve in Nigeria by showing that an inverse relationship exists between inflation and unemployment in the period under study. Author [2] employed the Ordinary Least Squares (OLS) technique in testing for the validity of the presence of the Phillips Curve in Nigeria using annual data for 1986-2014. The study reveals that the Phillips curve exists in Nigeria as there is a significant negative relationship between inflation and unemployment. $\mathrm{Au}-$ thor [11] mentioned that [9] found a negative relationship between inflation and unemployment in Nigeria. The finding by [17] cited by [31] validates Philip's curve hypothesis in the USA and UK.

This researcher's interest is to extend the period of analysis to 2020 to examine the variables better. Also, the study is extended to investigate the possible causes of inflation and unemployment in Nigeria. Additionally, the researcher employed preliminary tests such as unit roots and a descriptive test to avoid spurious regression.

\section{METHODOLOGY}

Research Design. The research design adopted in this study is an ex-post facto research design. By definition, the ex-post facto research design is a systematic empirical inquiry in which the researcher does not have control of independent variables because their manifestations have already occurred. Ex-post facto research design is adopted according to Kerlinger (1973) because the researcher is interested in investigating cause-effect relationships.

Model Specification. The researcher adopts the original Phillips equation as explained by [25] as cited by [30]:

$$
\begin{aligned}
& W=F(U), \\
& W=\alpha-\beta u,
\end{aligned}
$$

where $w$ is wage inflation; $U$ is unemployment; $\alpha$ is constant; $\beta$ is the unemployment coefficient or the slope.

Since $W=F(U)$, we can modify the model to fit our interest as:

$$
U=F(W) \text {. }
$$

Changes in nominal wage are used as a proxy for inflation.

If the inverse relationship between unemployment and inflation were genuine, the functional relationship should be:

$$
U=f\left(\frac{1}{W}\right)
$$

We can further modify equation (9) as:

$$
U M P R=f(I N F, G D P) .
$$

Descriptive statistics revealed that only inflation rate (INF) is a normal distribution, as shown by the probability value of Jaqua Bera statics which was more significant than 5\%. By modifying equation [33] to indicate the logged form, the mathematical form of the model becomes: 


\section{Model I}

$$
\mathrm{UMPR}_{\mathrm{t}}=\beta_{0}+\beta_{1} \mathrm{INF}_{\mathrm{t}}+\beta_{2} \mathrm{LGDP}_{\mathrm{t}}
$$

where $U M P R$ is the unemployment rate; INF represents inflation; $L G D P$ represents log of Gross Domestic Product; $f$ is the functional relationship. Converting equation [14] into an econometrics model, we have:

$$
U M P R_{t}=\beta_{0}+\beta_{1} I N F_{t}+\beta_{2} L G D P_{t}+\mu_{t}
$$

The study will also consider some factors that can affect inflation and unemployment in Nigeria due to the problematic levels of inflation and unemployment. These will be analyzed in separate models as given below.

\section{Model II}

In model two, the researcher aims at examining the effect of some variables on unemployment growth rates in Nigeria.

$$
\begin{aligned}
& U M P_{r}=f(I N V, G O V, C P S) \\
& U M P R_{t}=\beta_{0}+\beta_{1} I N V_{t}+\beta_{2} G O V_{t}+\beta_{3} C P S_{t}+U_{t}
\end{aligned}
$$

Model II regresses unemployment as a function of investment (INV), government expenditures (GOV) and credit to the private sector (CPS).

\section{Model III}

In model three, we shall regress inflation against some variables that may affect inflationary rates in Nigeria.

$$
\begin{aligned}
& I N F=f(M S, C O N, M A N Q) \\
& I N F_{t}=\beta_{0}+\beta_{1} M S_{t}+\beta_{2} C O N_{t}+\beta_{3} M A N Q_{t} \\
& +\beta_{4} A G R+\beta_{5} E X R+U_{t}
\end{aligned}
$$

Inflation represents inflation, MS is money supply (M2), CON represents final consumption, MANQ represents manufacturing output, and AGR represents the output from agriculture, while EXR is the exchange rate; $\mu$ trepresents the error term.
Priori Expectations. We expect to see an inverse relationship (-) between the dependent variables in the model I and II and their respective independent variables based on economic theories. In model three, there might be some controversies on the impacts of MS on inflation. Keynesian economies believe that it should be negative, assuming no full employment exists, while classical thoughts claim that it should be positive given full employment. However, judging by the Nigerian economy, we expect a negative relationship between manufacturing and agricultural output. On the other hand, we expect a positive relationship concerning final consumption, assuming that consumption increases faster than manufacturing and agricultural output. Depreciation in exchange rates makes imports costlier, and since Nigeria is an import-dependent country, it will lead to inflation.

Estimation Techniques. The data analysis started by conducting a unit root test. This was done to ensure that the research estimates were not spurious. In doing this, the Augmented Dickey-Fuller unit root test was employed. The techniques for further analysis were decided based on the outcomes of the unit root test and co-integration. The Vector Autoregressive (VAR) model was used in the model (I) due to the absence of cointegration. VAR model was also used in model two because the variables were integrated of the order of one and two. Finally, in model III, the Error Correction Model was employed because co-integration was found among the variables.

\section{RESULTS AND DISCUSSION}

Unit Root Test. Unit root test was done to avoid producing a spurious regression. The Augmented Dickey-Fuller unit root test was used. The result showed that all the variables used were stationary at first difference except for government expenditures after second differencing.

Model Estimation. First, we shall examine the relationship between inflation and unemployment in Nigeria.

\section{Model I}

$$
U M P R_{t}=\beta_{0}+\beta_{1} I N F_{t}+\beta_{2} L G D P_{t}
$$

According to economic theories, we expect the outcome of the model to be: 


$$
U M P R_{t}=\beta_{0}-\beta_{1} I N F_{t}-\beta_{2} L G D P_{t}
$$

Equation (16) implies that inflation and unemployment are inversely related. The model I is estimated using Johansen Co-integration Test, Vector Autoregressive Model and VAR Granger Causality Test. The results and analyses are given below.

Co-integration. The Johansen Co-integration test was employed to check for the existence or otherwise of a long-run relationship among the variables. The result showed the absence of a longrun relationship among the variables. The decision was made after observing that the values of trace statistics were less than 5\% critical in all hypothesized equations.

Given this, the Vector Autoregressive model is adopted to examine short-run relationships in the model. Furthermore, the VAR system equation is adopted to show the probability values.

Table 1 -Short Run Vector Autoregressive Model (I)

\begin{tabular}{|l|r|r|r|c|}
\hline & Coefficient & Std. Error & \multicolumn{1}{c|}{ t-Statistic } & Prob. \\
\hline UMPR & 0.623803 & 0.148788 & 4.192577 & 0.0002 \\
\hline INF & -0.057312 & 0.045773 & -1.252109 & 0.2188 \\
\hline GDP & 0.960902 & 0.420921 & 2.282854 & 0.0286 \\
\hline C & -2.229805 & 3.042535 & -0.732877 & 0.4685 \\
\hline
\end{tabular}

Notes: Researcher's Computation 2021, using E-views 9.0

Decision Rule. A coefficient of the parameter is assumed statistically significant in the probability value corresponding to it is less than $5 \%$.

From the VAR estimate above, we observe an inverse relationship between inflation and unemployment. Specifically, a change in inflation by $1 \%$ resulted in an inverse change in unemployment by approximately $6 \%$. We also observe a positive coefficient of 0.62 for unemployment corresponding to -0.06 for inflation, implying that both variables move in different directions.

However, the observed relationship between inflation and unemployment is insignificant. Using the inflation rate as the dependent variable, we found that an increase in unemployment resulted in a fall in the inflation rate by about $10 \%$. Yet, the estimate is insignificant (see appendix). These imply that other factors not included in the model must have played significant roles in changes in the variables.
When unemployment was used as a dependent variable, Gross Domestic Variable indicated a significant and positive impact on unemployment. An increase in GDP by $1 \%$ corresponds to an increase in unemployment by $96 \%$. It assumed an insignificant negative impact when inflation was used as the dependent variable. The first instance contradicts a priori expectations. It implies that economic growth in Nigeria propagates unemployment, while in the second instance, economic growth led to a fall in inflation rates by over $100 \%$. This does not conform to the situation in Nigeria. In Nigeria, there have not been coherent patterns in inflation and growth rates. For instance, periods of high growth rates corresponded with low inflation rates in some years. In some years, periods of recession also corresponded with high inflation rates (see appendix I).

Causality. A causality test was done to ascertain the degree of dependency among the variables. That is, to check if the variables granger caused each other. This will enable us to confirm the impacts explained in the VAR model.

Using unemployment (see table III in appendix) as the dependent variable, we notice that inflation does not cause unemployment in Nigeria, whereas; gross domestic product causes unemployment growth in Nigeria. These correspond to the insignificant impact obtained from inflation in the VAR model and the significant impact from GDP. Using the inflation rate as the dependent variable, we find that neither unemployment nor GDP causes inflation in Nigeria. This corresponds to the result obtained when inflation was used as the dependent variable in the VAR model (see appendix).

Conclusion on Model I. The inverse coefficients of inflation and unemployment confirm the acceptance of Philip's hypothesis in Nigeria.

We have established that inflation is not responsible for the significant and continuous rise in unemployment, neither is unemployment responsible for the changes in inflation. So the question now is, "what is responsible for the rapid and continuous increase in inflation and unemployment in Nigeria? The study further investigates factors that might have influenced the unemployment and inflation growth rate in Nigeria. This is done in models 2 and 3. 


\section{Model II}

$$
\mathrm{UMPR}_{\mathrm{t}}=\beta_{0}+\beta_{1} \mathrm{INV}_{\mathrm{t}}+\beta_{2} \mathrm{GOV}_{\mathrm{t}}+\beta_{3} \mathrm{CPS}_{\mathrm{t}}+\mathrm{U}_{\mathrm{t}}
$$

In this model, we try to examine some possible causes of unemployment growth in Nigeria. The researcher would like to know if investment, government spending, or credits to the private sector have significantly impacted the unemployment rate in Nigeria. The choice of these variables is as follows.

The ultimate goal of fiscal and monetary policies is to achieve full employment, economic growth etc. Investment is a critical path toward achieving those macroeconomic goals. This invests a channel for growth and reduced unemployment rate. If government fiscal policies fail, then we shall see investment increasing unemployment and vice versa. On the other hand, economists believe that the government can stimulate business activities, increase investment, reduce unemployment, and achieve economic growth in government spending. Also, one possible way of achieving these macroeconomic objectives is through access to credit for investment in private businesses. If these policy actions fail, then we shall expect positive coefficients.

Table 2 - Short Run Vector Autoregressive Model (II)

\begin{tabular}{|l|c|c|c|c|}
\hline & Coefficient & Std. Error & t-Statistic & Prob. \\
\hline UMPR (-1) & 0.604773 & 0.169496 & 3.568066 & 0.0013 \\
\hline UMPR(-2) & -0.137841 & 0.166654 & -0.827109 & 0.4149 \\
\hline INV(-1) & 9.670663 & 5.517283 & 1.752794 & 0.0902 \\
\hline INV(-2) & 8.903289 & 6.776674 & 1.313814 & 0.1992 \\
\hline GOV(-1) & 4.517269 & 3.551062 & 1.272090 & 0.2134 \\
\hline GOV(-2) & -7.266325 & 3.847279 & -1.888692 & 0.0690 \\
\hline CPS(-1) & -1.918450 & 4.527788 & -0.423706 & 0.6749 \\
\hline CPS(-2) & 9.018528 & 4.197531 & 2.148531 & 0.0402 \\
\hline C & -85.27211 & 25.87744 & -3.295229 & 0.0026 \\
\hline
\end{tabular}

Notes: Researcher's Computation 2021, using E-views 9.0

The estimation of model II reveals the following. First, at both lag one and optimum lag two, investment is shown to have no significant impact on unemployment rates in Nigeria. This is to say that policies aimed at stimulating investment in Nigeria may have been unsuccessful in increasing investment rates enough to impact unemployment significantly. Second, on the other hand, government expenditure is also shown to have insignificant impacts on unemployment. This reveals the inefficiencies in government spending over the years. The result conforms to the Global Competitiveness 2018 Index ranking Nigeria 120 of 137 on efficiency in government spending. Second, credit to the private sector is revealed to have a positive and significant impact on unemployment at lag two. This means that an increase in credit to the private sector by $1 \%$ led to an increase in unemployment by $9 \%$. There is, therefore, the need for efficiency in the allocation of funds to the private sector. Third, corruption in Nigeria has resulted in the wasteful allocation of funds to unproductive uses. This has to stop if Nigeria wants to see a significant drop in unemployment rates.
Conclusions on model II. Evidence from model II shows that investment and government spending have not significantly affected the unemployment rate levels in Nigeria. However, policies aimed at promoting investment in Nigeria have not been successful on the investment side. In contrast, government spending has not been efficiently done to achieve higher employment rates in Nigeria on government spending. Therefore, the researcher concludes that insufficient investment, inefficient government spending, and inefficient private credit allocation are the causes of unemployment in Nigeria.

\section{Model III}

$I N F_{t}=\beta_{0}+\beta_{1} M S_{t}+\beta_{2} \mathrm{CON}_{t}+$

$+\beta_{3} M A N Q_{t}+\beta_{4} A G R+\beta_{5} E X R+U_{t}$

Model III is used to explain the changes in inflation rates. The researcher considers money supply, final consumption, and manufacturing output 
as variables that can impact the inflation rate. The choice of these variables is as follows:

According to classical economists, money supply and inflation (price) directly relationship in the long run. However, this is only possible in the long run when output cannot be increased. In the short run, the output can be increased. Thus, the manufacturing output will not affect the price with an increase in money supply and a corresponding investment increase. It might even further reduce inflation if the changes in investment and investment are more than the changes in the money supply. Concerning final consumption, demand-pull inflation can result from an increase in aggregate demand oversupply. Food inflation is one of the most observed inflation in Nigeria.

Given the low-income level in Nigeria, a more significant percentage of income is spent on food. Estimates from model III is given below. The fact that Nigeria is an import-dependent nation makes the concept of exchange rate vital. A large proportion of components used in the production processes in Nigeria is imported. A depreciation in the value of naira (as it had been) will make imports costlier and thus, reflect positively on price.

Table 3 - Short Run Error Vector Correction Model (III)

\begin{tabular}{|l|c|c|c|c|}
\hline & Coefficient & Std. Error & t-Statistic & Prob. \\
\hline ECM & -0.075160 & 0.031532 & -2.383580 & 0.0258 \\
\hline AGR(-1) & 24.19718 & 19.10264 & 1.266693 & 0.2179 \\
\hline AGR(-2) & -3.634807 & 17.15367 & -0.211897 & 0.8341 \\
\hline MANQ(-1) & 10.09886 & 20.67700 & 0.488410 & 0.6299 \\
\hline MANQ(-2) & -7.429210 & 22.93686 & -0.323898 & 0.7489 \\
\hline CON(-2) & -27.27855 & 11.79530 & -2.312663 & 0.0300 \\
\hline MS(-1) & 53.08108 & 23.99697 & 2.211990 & 0.0372 \\
\hline EXR(-1) & 29.90529 & 13.42189 & 2.228097 & 0.0359 \\
\hline EXR(-2) & 42.38710 & 12.29437 & 3.447682 & 0.0022 \\
\hline C & -20.26785 & 9.369175 & -2.163248 & 0.0412 \\
\hline
\end{tabular}

Notes: Researcher's Computation 2021, using E-views 9.0

A lot of variables can influence the inflation rate. However, the researcher considers the above variables as most influential.
The estimate of model three above reveals that agricultural and manufacturing outputs have an insignificant impact on inflation.

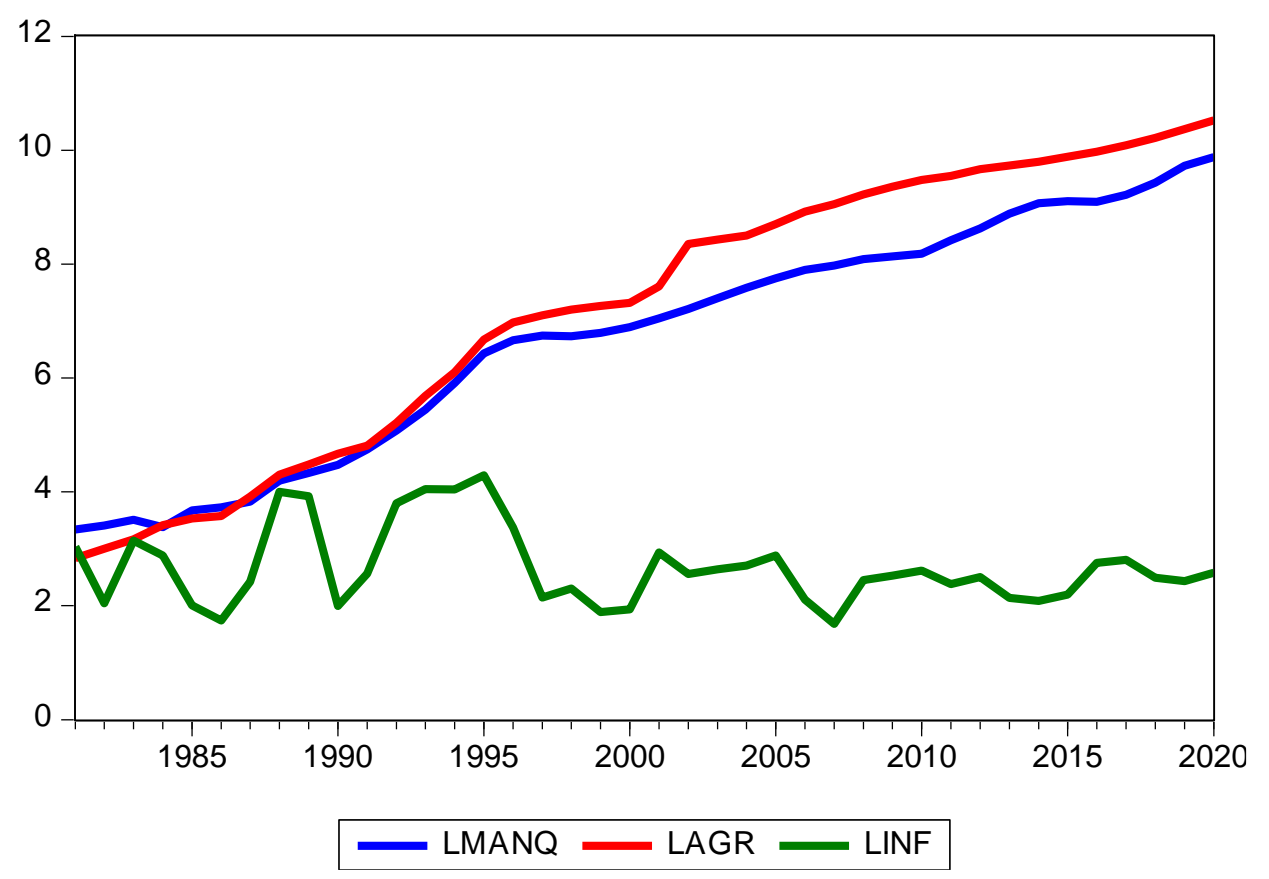

Figure 2 - Inflation and Output Trends

Notes: Researcher's Computation 2021, using E-views 9.0 
The trend lines above show that there has been a smooth ride in both agricultural and manufacturing outputs over time. It also proves that there is no significant relationship between output and inflation in Nigeria.

Final consumption was revealed to have a significant negative impact on inflation at lag two. On the other hand, the estimate was insignificant at lag one. On the other hand, the money supply at lag one indicated a positive and significant impact on inflation. This implies that the money supply has not been able to significantly improve outputs levels given the increasing levels of consumption/demand, hence, leading to inflation. There is, therefore, a need to increase the money supply and efficiently link up investment.

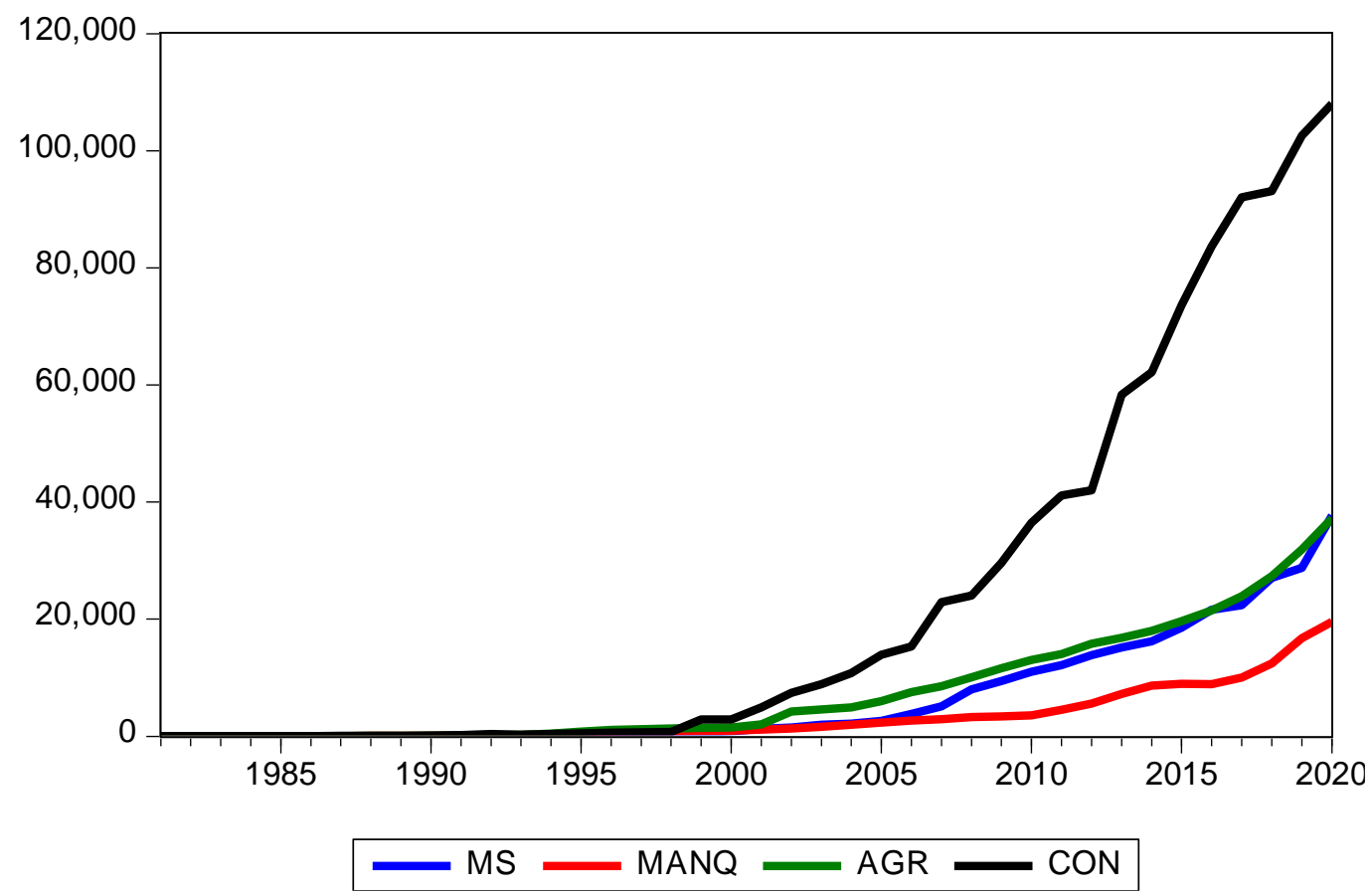

Figure 3 - Money Supply, Manufacturing and Agricultural outputs and Consumption

Source: Researcher's Computation 2021, using E-views 9.0

Figure 3 above reveals the gap between output and final consumption. There is, therefore, the need to bridge this gap through an increase in investment and output. One of the ways of achieving this is through monetary policies such as efficient use of money supply.

At lag one and two, exchange rates were shown to have positive and significant impacts on inflation rates. Relating this observation to the current realities of present 2021, one can conclude this estimate's truism. The rapid depreciation of the naira against the dollar saw the inflation rate rise to $17.75 \%$ in June 2021 . This corresponds to depreciation in the exchange rate from $358.8 / \$$ in 2020 to $404.19 / \$$ in June 2021 . The figure is expected to be higher in July 2021. This relationship is due to the high levels of import dependency in Nigeria and the low demand for naira due to the low competitiveness of the export sector.
Conclusion on Model III. The researcher concludes on the estimates on model III by saying that exchange rate depreciation and increase in the money supply without corresponding or more than proportional increase in output is the primary cause of inflation in Nigeria. Therefore, there is a need to stimulate investment and output using efficient monetary and fiscal policies. An increase in output will match the increasing levels of consumption and drive export and increase the competitiveness of naira and, hence, improve the exchange rate position of naira and ultimately reduce inflation.

Post Estimation Test. Post estimation test was done to see how seriously the regression estimates will be taken. It was done to check if the result is only valid for the period of analysis only or if it can be used for forecasts and further predictions. LM serial correlation was used. The LM serial correlation test was employed to check if 
the previous values determined the current value of the error term. The error term assumes that the mean, variance and co-variance are timeinvariant.

The result of the serial correlation test from the three models indicated the absence of serial correlation in the models.

The implication of the study. The primary objective of this study is to investigate the validity of the Philips Curve in Nigeria for the periods between 1981 and 2020. The study also took an interest in identifying the possible causes of inflation and unemployment in Nigeria within the same timeframe.

The study found out that inflation and unemployment moved in the opposite direction and that they both have an insignificant impact. Investigation on the possible causes of unemployment revealed that the government had not stimulated employment in the country through its expenditures. The study found that there have been insufficient investments to reduce the levels of unemployment rates in Nigeria. Another factor observed was inefficiencies in allocating private credits. As a result, private credits were revealed to have encouraged unemployment growth in Nigeria.

In the area of inflation, the study found that exchange rate depreciation and money supply had positive and significant impacts on inflation. Exchange rate depreciation and money supply were considered the primary causes of Nigeria's increasing levels of inflation. This reveals the low competitiveness of naira due to the country's weak export sector and huge import sector. Therefore, there is a need to match money supply with output to meet local demands and export needs.

\section{CONCLUSIONS}

Summary of Findings. The study examined the relationship between Unemployment and Inflation: Testing Philip's Curve Hypotheses and investigating the causes of inflation and unemployment in Nigeria. The study covered periods between 1981 and 2020 .

The resulting finding includes that:

1. Philip's hypothesis exists in Nigeria.

2. Inflation and unemployment have no significant relationship.
3. There is no long-run relationship between inflation and unemployment in Nigeria.

4. No causality exists between inflation and unemployment in Nigeria.

5. Insufficient investment, efficient government spending and inefficient allocation of private credits are the causes of unemployment growth in Nigeria.

6. Exchange rate depreciation and an increase in the money supply without a corresponding increase in output are the primary causes of inflation in Nigeria.

Recommendation. The study examined the relationship between Unemployment and Inflation: Testing Philips Curve Hypotheses and investigating the causes of inflation and unemployment in Nigeria. The study validates the existence of the Philips curve in Nigeria for the periods under review. Inflation and unemployment were shown to have an insignificant relationship. The study identified inefficiencies in government spending, private credit allocation, and insufficient investment levels as possible causes of unemployment growth in Nigeria. At the same time, money supply and exchange rate depreciation were considered the primary causes of inflation in Nigeria.

The study concludes that the problems of inflation and unemployment arise from inefficiencies in both monetary and fiscal policies. That there is need to improve on the efficiency at which government spends money. There is also a need to stimulate investment using monetary and fiscal policies and efficient private credit allocation to its best uses. The study recommends that the central bank and the ministry of finance should do everything in their capacity to raise the output levels to match or surpass the increasing levels of domestic demand while also making provisions to stimulate export to make the naira more competitive. This implies the efficient use of fiscal and monetary policy measures, including the money supply. Also, the study recommends the full implementation of economic diversification policies. Furthermore, there is a need to increase government spending on social infrastructure and incentives to firms to promote investment in Nigeria. These will have an overall effect of increasing output, reducing unemployment and promoting non-inflationary growth in Nigeria. 


\section{REFERENCES}

1. Ademola, A., Badiru, A. (2016). The impact of unemployment and inflation on economic growth in Nigeria (1981-2014). International Journal of Business and Economic Sciences Applied Research, 9(1), 47-55

2. Ajie, H., A., Ani, E. C., \&Ameh, O. E. (2017). An Examination of the Impact of Unemployment and Inflation on the Nigerian Economy: A Bounds Testing Approach.Journal of Public Policy and Administration, 1(1), 22-34.

3. Alisa, M. (2015). The Relationship between Inflation and Unemployment: A Theoretical Discussion about the Philips Curve. Journal of International Business and Economics, 3(2). doi: 10.15640/jibe.v3n2a7

4. Balami, D. (2006). Macroeconomic theory and practice. Wulari: Salawe prints.

5. Bregger, J. (1971). Unemployment statistics and what they mean. Monthly Labor Review, 94(11), 2229.

6. Buba, S., \&Aljadi, S. (2017). Inflation and unemployment in Nigeria: An ARDL approach.World Journal of Economic and Finance, 32, 69-74.

7. Central Bank of Nigeria. (2003). Annual report and statement of account. Retrieved from https://www.cbn.gov.ng/OUT/PUBLICATIONS/REPORTS/RD/2003/CBN\%20ANNUAL\%20RE PORT\%201.PDF

8. Central Bank of Nigeria. (2020). Statistical bulletin. Abuja: Central Bank of Nigeria.

9. Edeme, R. K. (2018). Providing an Empirical Insight into Nigeria's Non-acceleration Rate of Unemployment. Journal of Development Policy and Practice, 3(2), 179-190. doi: $10.1177 / 2455133318777161$

10. Efayena, O. O., \& Olele, H. E. (2020). A validation of the Phillips curve hypothesis in Nigeria: $A$ quarterly data based approach. Retrieved from https://mpra.ub.unimuenchen.de/98804/1/MPRA_paper_98804.pdf

11. Emmanuel, U. (2019). Inflation and Unemployment Dynamics in Nigeria: A Re-examination of the Philip's Curve Theory. International Journal of Scientific and Research Publications, 9(1), 85-108. doi: 10.29322/ijsrp.9.01.2019.p85108

12. Fisher, M. E., \& Seater, J. J. (1993). Long-Run Neutrality and Superneutrality in an ARIMA Framework. The American Economic Review, 83(3), 402-415.

13. Friedman, M. (1976). Inflation and unemployment. Retrieved from https://www.nobelprize.org/uploads/2018/06/friedman-lecture-1.pdf

14. Furuoka, F. (2007). Does the Phillips curve really exist? New empirical evidence from Malaysia. Retrieved from https://www.researchgate.net/publication/4830630_Does_the_Phillips_Curve_Really_Exist_Ne w_Empirical_Evidence_from_Malaysia

15. Gbosi, A. (2006). Modern labour economics and policy analysis. Lagos: Dove Publisher.

16. Grill, E., \&Zanalda, G. (1995). Growth and employment in developing countries: Where do we stand?Torino: Centro Studi Luca D'Agliano.

17. Hasanov, F. (2011, June). Relationship between inflation and economic growth in Azerbaijani economy: is there any threshold effect? Retrieved from https://mpra.ub.unimuenchen.de/33494/3/MPRA_paper_33494.pdf

18. Hussain, M., \&Nadol, C. (1997). Employment, growth and the demand side: The case of some African countries. Abidjan: The African Development Bank. 
19. Idenyi, O., Favour, E.-O., Johnson, N., \& Thomas, O. (2017). Understanding the Relationship between Unemployment and Inflation in Nigeria. Advances in Research, 9(2), 1-12. doi: 10.9734/air/2017/32218

20. Isa, C., \&Joel, E. (2018). Applicability and the working of Phillips curve on the Nigerian economy. Retrieved from https://fud.edu.ng/journals/dujeds/2018_DEC_Vol_6_No_2/DUJEDS\%20026_CHARITY2.pdf

21. Iyeli, I., \& Ekpung, E. (2017). Price expectation and the Philips curve hypothesis: the Nigeria case.International Journal of Development and Economic Sustainability, 5(4), 1-10.

22. Jelilov, G., Obasa, O., \& Isik, A. (2016). The impact of inflation on unemployment in Nigeria (20012013). Sacha Journal of Policy and Strategic Studies, 6(1) 28-34.

23. Jhingan, M. L. (2003). Advanced macroeconomic theory (11th ed.). Delhi: Vrinda Publications.

24. Karanassou, M., Sala, H., \& Snower, D. (2010). Phillips curve and unemployment dynamics: A critique and a Holistic Perspective. Retrieved from https://ftp.iza.org/dp2265.pdf

25. Keynes, J. (1936).The general theory of employment, interest and money. London: Macmillan.

26. Okafor, I. G., Ezeaku, H. C., \&Ugwuebe, S. U. (2016). Responsiveness of unemployment to inflation: Empirical evidence from Nigeria.International Journal of Scientific Research in Science and Technology, 2(4), 173-179.

27. Orji, A., Orji, O. I. A., \& Okafor, J. C. (2015). Inflation And Unemployment Nexus In Nigeria: Another Test of the Phillips Curve. Asian Economic and Financial Review, 5(5), 766-778. doi: 10.18488/journal.aefr/2015.5.5/102.5.766.778

28. Phillips, A. W. (1958). The Relation between Unemployment and the Rate of Change of Money Wage Rates in the United Kingdom, 1861-1957. Economica, 25(100), 283-299. doi: $10.2307 / 2550759$

29. Ribba, A. (2003). Short-run and long-run interaction between inflation and unemployment in the USA. Applied Economics Letters, 10(6), 373-376. doi: 10.1080/1350485032000081983

30. Singh, D., \& Verma, N. (2016). Tradeoff between Inflation and Unemployment in the Short Run: A Case of the Indian Economy. International Finance and Banking, 3(1), 77. doi: 10.5296/ifb.v3i1.9378

31. Sualihu, B. M. (2016). Examining the nexus between inflation and unemployment in Ghana: The Philips curve model (Master's dissertation). Retrieved from https://www.coursehero.com/file/97640213/FINAL-THESISpdf/

32. The World Bank. (2020). Development Indicators. Retrieved from https://data.worldbank.org/indicator

33. Umoru, D., \&Anyiwe, M. (2013). Dynamics of inflation and unemployment in a vector error correction model.Research on Humanities and Social Sciences, 3(3), 20-30

34. Yelwa, M., David, O. O. K., \& Omoniyi, A. (2015). Analysis of the Relationship between Inflation, Unemployment and Economic Growth in Nigeria: 1987-2012. Applied Economics and Finance, 2(3). doi: 10.11114/aef.v2i3.943 
Data for Empirical Analysis

\begin{tabular}{|c|c|c|c|c|c|}
\hline YEAR & $\begin{array}{l}\text { Unemployme } \\
\text { nt Rate (\%) }\end{array}$ & $\begin{array}{c}\text { Inflation Rate } \\
(\%)\end{array}$ & $\begin{array}{c}\text { Government expenditures } \\
\left(\mathbb{N}^{\prime} \mathrm{B}\right)\end{array}$ & $\begin{array}{l}\text { Money Supply } \\
\left(\mathrm{A}^{\prime} \mathrm{B}\right)\end{array}$ & Exchange Rate $(\mathrm{N} / \$)$ \\
\hline 1981 & 5.2 & 20.8128 & 11.41 & 14.47 & 0.6 \\
\hline 1982 & 4.3 & 7.6977 & 11.92 & 15.79 & 0.7 \\
\hline 1983 & 6.4 & 23.2123 & 9.64 & 17.69 & 0.7 \\
\hline 1984 & 6.2 & 17.8205 & 9.93 & 20.11 & 0.8 \\
\hline 1985 & 6.1 & 7.4353 & 13.04 & 22.30 & 0.9 \\
\hline 1986 & 5.3 & 5.7172 & 16.23 & 23.81 & 1.8 \\
\hline 1987 & 7 & 11.2903 & 22.02 & 27.57 & 4 \\
\hline 1988 & 5.1 & 54.5112 & 27.75 & 38.36 & 4.5 \\
\hline 1989 & 4.5 & 50.4667 & 41.03 & 45.90 & 7.4 \\
\hline 1990 & 3.5 & 7.3644 & 60.27 & 47.42 & 8 \\
\hline 1991 & 3.1 & 13.007 & 66.58 & 75.40 & 9.9 \\
\hline 1992 & 3.5 & 44.5888 & 92.80 & 111.11 & 17.3 \\
\hline 1993 & 3.4 & 57.1653 & 191.23 & 165.34 & 22.1 \\
\hline 1994 & 3.2 & 57.0317 & 160.89 & 230.29 & 22 \\
\hline 1995 & 1.9 & 72.8355 & 248.77 & 289.09 & 21.9 \\
\hline 1996 & 2.8 & 29.2683 & 337.22 & 345.85 & 21.9 \\
\hline 1997 & 3.4 & 8.5299 & 428.22 & 413.28 & 21.9 \\
\hline 1998 & 3.5 & 9.9964 & 487.11 & 488.15 & 21.9 \\
\hline 1999 & 17.5 & 6.6184 & 947.69 & 628.95 & 92.3 \\
\hline 2000 & 18.1 & 6.9333 & 701.05 & 878.46 & 101.7 \\
\hline 2001 & 13.7 & 18.8736 & $1,018.00$ & $1,269.32$ & 111.2 \\
\hline 2002 & 12.2 & 12.8766 & $1,018.18$ & $1,505.96$ & 120.6 \\
\hline 2003 & 14.8 & 14.0318 & $1,225.99$ & $1,952.92$ & 129.2 \\
\hline 2004 & 11.8 & 14.998 & $1,426.20$ & $2,131.82$ & 132.9 \\
\hline 2005 & 11.9 & 17.8635 & $1,822.10$ & $2,637.91$ & 131.3 \\
\hline 2006 & 12.3 & 8.2252 & $1,938.00$ & $3,797.91$ & 128.7 \\
\hline 2007 & 12.7 & 5.388 & $2,450.90$ & $5,127.40$ & 125.8 \\
\hline 2008 & 14.7 & 11.5811 & $3,240.82$ & $8,008.20$ & 118.6 \\
\hline 2009 & 19.7 & 12.555 & $3,452.99$ & $9,411.11$ & 148.9 \\
\hline 2010 & 21.1 & 13.7202 & $4,194.58$ & $11,034.94$ & 150.3 \\
\hline 2011 & 23.9 & 10.84 & $4,712.06$ & $12,172.49$ & 153.9 \\
\hline 2012 & 27.4 & 12.2178 & $4,605.39$ & $13,893.22$ & 157.5 \\
\hline 2013 & 10 & 8.4758 & $5,185.32$ & $15,154.64$ & 157.3 \\
\hline 2014 & 7.8 & 8.0625 & $4,587.39$ & $16,238.52$ & 158.6 \\
\hline 2015 & 10.4 & 9.0094 & $4,988.86$ & $18,525.22$ & 192.4 \\
\hline 2016 & 13.4 & 15.6753 & $5,858.56$ & $21,624.63$ & 253.5 \\
\hline 2017 & 23.1 & 16.5235 & $6,456.70$ & $22,363.43$ & 305.8 \\
\hline 2018 & 22.6 & 12.0947 & $7,813.74$ & $27,068.58$ & 306.1 \\
\hline 2019 & 23.1 & 11.3968 & $9,714.84$ & $28,783.19$ & 306.9 \\
\hline 2020 & 33.3 & 13.25 & $10,164.6$ & $37,704.98$ & 358.8 \\
\hline
\end{tabular}




\begin{tabular}{|c|c|c|c|c|c|}
\hline YEAR & $\begin{array}{l}\text { Credit To } \\
\text { Private } \\
\text { Sector(A'B) }\end{array}$ & $\begin{array}{c}\text { Consumption } \\
\text { expenditures }\left(\mathrm{N}^{\prime} \mathrm{B}\right)\end{array}$ & $\begin{array}{l}\text { Agricultural } \\
\left.\text { Output( } \mathbb{N}^{\prime} B\right)\end{array}$ & 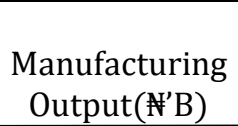 & GDP( $\left.\mathrm{A}^{\prime} \mathrm{B}\right)$ \\
\hline 1981 & 8.57 & 9.704794 & 17.05 & 28.23 & 94.33 \\
\hline 1982 & 10.67 & 12.3445 & 20.13 & 30.31 & 101.01 \\
\hline 1983 & 11.67 & 14.37329 & 23.80 & 33.49 & 110.06 \\
\hline 1984 & 12.46 & 20.95202 & 30.37 & 29.42 & 116.27 \\
\hline 1985 & 13.07 & 31.77033 & 34.24 & 39.55 & 134.59 \\
\hline 1986 & 15.25 & 41.19434 & 35.70 & 41.63 & 134.6 \\
\hline 1987 & 21.08 & 88.87418 & 50.29 & 45.96 & 193.13 \\
\hline 1988 & 27.33 & 110.3806 & 73.76 & 66.34 & 263.29 \\
\hline 1989 & 30.40 & 97.28678 & 88.26 & 76.14 & 382.26 \\
\hline 1990 & 33.55 & 149.4343 & 106.63 & 87.96 & 472.65 \\
\hline 1991 & 41.35 & 189.1657 & 123.24 & 115.03 & 545.67 \\
\hline 1992 & 58.12 & 367.543 & 184.12 & 159.95 & 875.34 \\
\hline 1993 & 127.12 & 287.9516 & 295.32 & 231.02 & 1089.68 \\
\hline 1994 & 143.42 & 387.8546 & 445.27 & 370.16 & 1399.7 \\
\hline 1995 & 180.00 & 509.6081 & 790.14 & 619.85 & 2907.36 \\
\hline 1996 & 238.60 & 633.9054 & $1,070.51$ & 780.48 & 4032.3 \\
\hline 1997 & 316.21 & 653.2192 & $1,211.46$ & 848.33 & 4189.25 \\
\hline 1998 & 351.96 & 729.4532 & $1,341.04$ & 838.53 & 3989.45 \\
\hline 1999 & 431.17 & 2853.154 & $1,426.97$ & 891.29 & 4679.21 \\
\hline 2000 & 530.37 & 2875.752 & $1,508.41$ & 984.08 & 6713.57 \\
\hline 2001 & 764.96 & 4960.88 & $2,015.42$ & $1,146.68$ & 6895.2 \\
\hline 2002 & 930.49 & 7435.046 & $4,251.52$ & $1,358.53$ & 7795.76 \\
\hline 2003 & $1,096.54$ & 8877.419 & $4,585.93$ & $1,635.05$ & 9913.52 \\
\hline 2004 & $1,421.66$ & 10781.65 & $4,935.26$ & $1,968.56$ & 11411.07 \\
\hline 2005 & $1,838.39$ & 13935.37 & $6,032.33$ & $2,326.31$ & 14610.88 \\
\hline 2006 & $2,290.62$ & 15358.25 & $7,513.30$ & $2,689.08$ & 18564.59 \\
\hline 2007 & $3,668.66$ & 22944.05 & $8,551.98$ & $2,913.26$ & 20657.32 \\
\hline 2008 & $7,899.14$ & 24035.71 & $10,100.33$ & $3,263.82$ & 24296.33 \\
\hline 2009 & $9,889.58$ & 29596.28 & $11,625.44$ & $3,406.69$ & 24794.24 \\
\hline 2010 & $10,518.17$ & 36485.28 & $13,048.89$ & $3,578.64$ & 54612.26 \\
\hline 2011 & $9,600.02$ & 41154.18 & $14,037.83$ & $4,527.45$ & 62980.4 \\
\hline 2012 & $13,293.64$ & 42037.07 & $15,816.00$ & $5,588.82$ & 71713.94 \\
\hline 2013 & $14,461.41$ & 58324.62 & $16,816.55$ & $7,233.32$ & 80092.56 \\
\hline 2014 & $16,753.00$ & 62207.36 & $18,018.61$ & $8,685.43$ & 98043.62 \\
\hline 2015 & $18,688.42$ & 73593.88 & $19,636.97$ & $8,973.77$ & 94144.96 \\
\hline 2016 & $21,025.24$ & 83637.89 & $21,523.51$ & $8,903.24$ & 101598.48 \\
\hline 2017 & $22,459.18$ & 92068.35 & $23,952.55$ & $10,044.48$ & 113711.6346 \\
\hline 2018 & $22,646.33$ & 93125.36 & $27,371.30$ & $12,455.53$ & $127,736.83$ \\
\hline 2019 & $25,676.87$ & 102587.9 & $31,904.14$ & $16,781.06$ & $144,210.49$ \\
\hline 2020 & $29,051.61$ & 108007.5 & $37,241.61$ & $19,539.55$ & $152,324.07$ \\
\hline
\end{tabular}

Data Source: Central Bank of Nigeria Statistical Bulletin, 2020 and World Bank Data, 2020. 


\section{Regression Results}

Model I:

Table I: Co-Integration

Unrestricted Cointegration Rank Test (Trace)

\begin{tabular}{ccccc}
\hline \hline $\begin{array}{c}\text { Hypothesized } \\
\text { No. of CE(s) }\end{array}$ & Eigenvalue & $\begin{array}{c}\text { Trace } \\
\text { Statistic }\end{array}$ & $\begin{array}{c}0.05 \\
\text { Critical Value }\end{array}$ & Prob.** \\
\hline \hline None & 0.385181 & 27.43528 & 29.79707 & 0.0914 \\
At most 1 & 0.192165 & 9.437440 & 15.49471 & 0.3265 \\
At most 2 & 0.040812 & 1.541734 & 3.841466 & 0.2144 \\
\hline \hline
\end{tabular}

Trace test indicates no cointegration at the 0.05 level

* denotes rejection of the hypothesis at the 0.05 level

**MacKinnon-Haug-Michelis (1999) p-values

Unrestricted Cointegration Rank Test (Maximum Eigenvalue)

\begin{tabular}{ccccc}
\hline \hline $\begin{array}{c}\text { Hypothesized } \\
\text { No. of CE(s) }\end{array}$ & Eigenvalue & $\begin{array}{c}\text { Max-Eigen } \\
\text { Statistic }\end{array}$ & $\begin{array}{c}0.05 \\
\text { Critical Value }\end{array}$ & Prob.** \\
\hline \hline None & 0.385181 & 17.99784 & 21.13162 & 0.1299 \\
At most 1 & 0.192165 & 7.895706 & 14.26460 & 0.3894 \\
At most 2 & 0.040812 & 1.541734 & 3.841466 & 0.2144 \\
\hline \hline
\end{tabular}

Max-eigenvalue test indicates no cointegration at the 0.05 level

* denotes rejection of the hypothesis at the 0.05 level

**MacKinnon-Haug-Michelis (1999) p-values

Unrestricted Cointegrating Coefficients (normalized by $b^{\prime *} S 11 * b=I$ ):

\begin{tabular}{ccc}
\hline \hline UMPR & INF & LGDP \\
-0.214103 & -0.126217 & 0.349013 \\
0.229418 & -0.016886 & -0.619333 \\
0.118210 & 0.032913 & 0.221344 \\
\hline \hline
\end{tabular}

Unrestricted Adjustment Coefficients (alpha):

\begin{tabular}{crrr}
\hline \hline D(UMPR) & 1.179047 & -1.774636 & -0.064696 \\
D(INF) & 4.123707 & 2.387998 & -1.927964 \\
D(LGDP) & -0.058522 & -0.010271 & -0.028450 \\
\hline \hline & & & \\
1 Cointegrating Equation(s): & Log likelihood & -231.5194 \\
\hline \hline
\end{tabular}

Normalized cointegrating coefficients (standard error in parentheses)

$\begin{array}{ccc}\text { UMPR } & \text { INF } & \text { LGDP } \\ 1.000000 & 0.589514 & -1.630114 \\ & (0.11386) & (0.52682)\end{array}$


Table II: Vector Autoregression Estimates

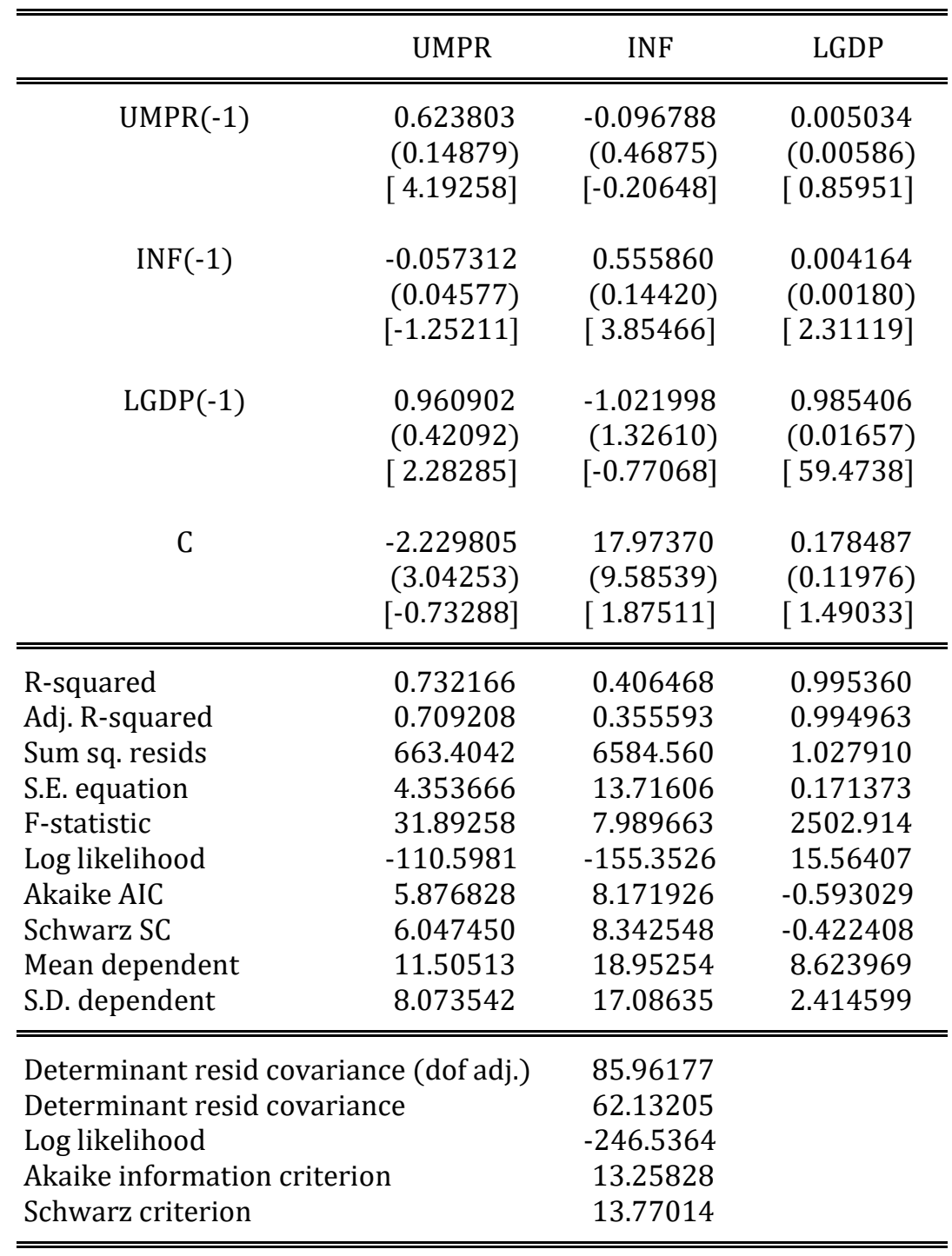

Table III: VAR Causality

Dependent variable: UMPR

\begin{tabular}{cccc}
\hline \hline Excluded & Chi-sq & df & Prob. \\
\hline \hline INF & 1.567777 & 1 & 0.2105 \\
LGDP & 5.211423 & 1 & 0.0224 \\
\hline \hline All & 6.618573 & 2 & 0.0365 \\
\hline \hline
\end{tabular}

Dependent variable: INF

\begin{tabular}{llll}
\hline \hline Excluded & Chi-sq & df & Prob. \\
\hline \hline
\end{tabular}




\begin{tabular}{cccc} 
UMPR & 0.042635 & 1 & 0.8364 \\
LGDP & 0.593950 & 1 & 0.4409 \\
\hline \hline All & 1.657176 & 2 & 0.4367 \\
\hline \hline
\end{tabular}

Dependent variable: LGDP

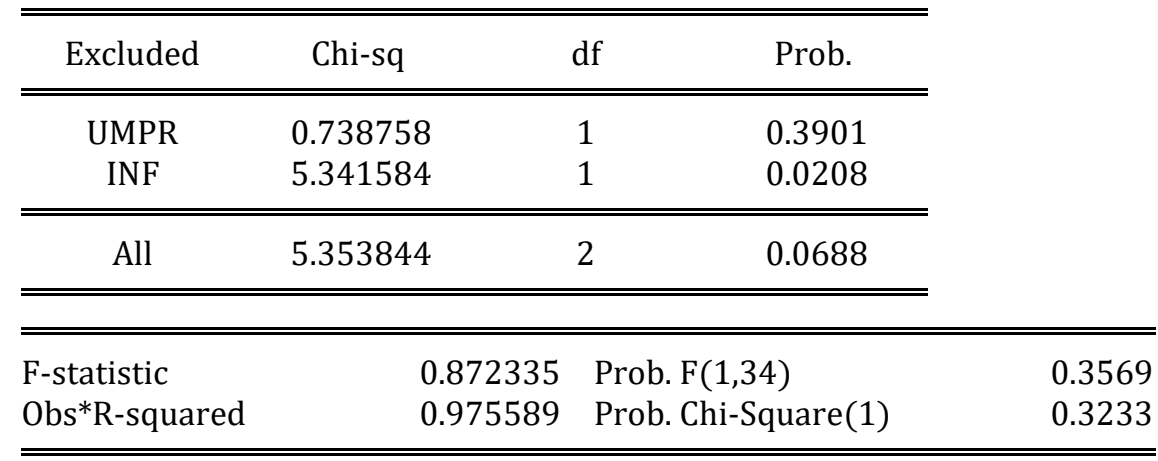

Table IV: Inflation as Dependent Variable

Vector Autoregression Estimates

\begin{tabular}{lrrr}
\hline \hline & INF & UMPR & LGDP \\
\hline \hline \multicolumn{1}{c}{ INF(-1) } & 0.555860 & -0.057312 & 0.004164 \\
& $(0.14420)$ & $(0.04577)$ & $(0.00180)$ \\
& {$[3.85466]$} & {$[-1.25211]$} & {$[2.31119]$} \\
\multicolumn{1}{c}{ UMPR(-1) } & -0.096788 & 0.623803 & 0.005034 \\
& $(0.46875)$ & $(0.14879)$ & $(0.00586)$ \\
& {$[-0.20648]$} & {$[4.19258]$} & {$[0.85951]$} \\
\multicolumn{1}{c}{ LGDP(-1) } & -1.021998 & 0.960902 & 0.985406 \\
& $(1.32610)$ & $(0.42092)$ & $(0.01657)$ \\
& {$[-0.77068]$} & {$[2.28285]$} & {$[59.4738]$} \\
& & & \\
& 17.97370 & -2.229805 & 0.178487 \\
& $(9.58539)$ & $(3.04253)$ & $(0.11976)$ \\
& {$[1.87511]$} & {$[-0.73288]$} & {$[1.49033]$} \\
\hline \hline R-squared & 0.406468 & 0.732166 & 0.995360 \\
Adj. R-squared & 0.355593 & 0.709208 & 0.994963 \\
Sum sq. resids & 6584.560 & 663.4042 & 1.027910 \\
S.E. equation & 13.71606 & 4.353666 & 0.171373 \\
F-statistic & 7.989663 & 31.89258 & 2502.914 \\
Log likelihood & -155.3526 & -110.5981 & 15.56407 \\
Akaike AIC & 8.171926 & 5.876828 & -0.593029 \\
Schwarz SC & 8.342548 & 6.047450 & -0.422408 \\
Mean dependent & 18.95254 & 11.50513 & 8.623969 \\
S.D. dependent & 17.08635 & 8.073542 & 2.414599 \\
\hline \hline
\end{tabular}




\section{Model II}

Table V: Vector Autoregression Estimates

\begin{tabular}{|c|c|c|c|c|}
\hline & UMPR & LINV & LGOV & LCPS \\
\hline $\operatorname{UMPR}(-1)$ & $\begin{array}{c}0.604773 \\
(0.16950) \\
{[3.56807]}\end{array}$ & $\begin{array}{r}-0.001962 \\
(0.00558) \\
{[-0.35168]}\end{array}$ & $\begin{array}{r}-0.001514 \\
(0.00875) \\
{[-0.17300]}\end{array}$ & $\begin{array}{r}-0.001698 \\
(0.00741) \\
{[-0.22913]}\end{array}$ \\
\hline $\operatorname{UMPR}(-2)$ & $\begin{array}{r}-0.137841 \\
(0.16665) \\
{[-0.82711]}\end{array}$ & $\begin{array}{c}0.002740 \\
(0.00548) \\
{[0.49948]}\end{array}$ & $\begin{array}{r}-0.008496 \\
(0.00861) \\
{[-0.98710]}\end{array}$ & $\begin{array}{c}0.000121 \\
(0.00729) \\
{[0.01659]}\end{array}$ \\
\hline $\operatorname{LINV}(-1)$ & $\begin{array}{c}9.670663 \\
(5.51728) \\
{[1.75279]}\end{array}$ & $\begin{array}{c}1.051042 \\
(0.18158) \\
{[5.78820]}\end{array}$ & $\begin{array}{r}-0.102830 \\
(0.28494) \\
{[-0.36089]}\end{array}$ & $\begin{array}{r}-0.241153 \\
(0.24119) \\
{[-0.99984]}\end{array}$ \\
\hline $\operatorname{LINV}(-2)$ & $\begin{array}{c}8.903289 \\
(6.77667) \\
{[1.31381]}\end{array}$ & $\begin{array}{r}-0.268215 \\
(0.22303) \\
{[-1.20258]}\end{array}$ & $\begin{array}{r}-0.447362 \\
(0.34998) \\
{[-1.27826]}\end{array}$ & $\begin{array}{r}-0.043207 \\
(0.29625) \\
{[-0.14585]}\end{array}$ \\
\hline $\operatorname{LGOV}(-1)$ & $\begin{array}{c}4.517269 \\
(3.55106) \\
{[1.27209]}\end{array}$ & $\begin{array}{c}0.154400 \\
(0.11687) \\
{[1.32111]}\end{array}$ & $\begin{array}{c}0.674530 \\
(0.18339) \\
{[3.67806]}\end{array}$ & $\begin{array}{r}0.025041 \\
(0.15524) \\
{[0.16131]}\end{array}$ \\
\hline LGOV(-2) & $\begin{array}{r}-7.266325 \\
(3.84728) \\
{[-1.88869]}\end{array}$ & $\begin{array}{r}-0.194765 \\
(0.12662) \\
{[-1.53817]}\end{array}$ & $\begin{array}{c}0.468133 \\
(0.19869) \\
{[2.35609]}\end{array}$ & $\begin{array}{r}0.190850 \\
(0.16819) \\
{[1.13475]}\end{array}$ \\
\hline LCPS(-1) & $\begin{array}{r}-1.918450 \\
(4.52779) \\
{[-0.42371]}\end{array}$ & $\begin{array}{r}-0.020027 \\
(0.14902) \\
{[-0.13439]}\end{array}$ & $\begin{array}{r}-0.238225 \\
(0.23384) \\
{[-1.01877]}\end{array}$ & $\begin{array}{c}1.001186 \\
(0.19793) \\
{[5.05816]}\end{array}$ \\
\hline LCPS(-2) & $\begin{array}{c}9.018528 \\
(4.19753) \\
{[2.14853]}\end{array}$ & $\begin{array}{c}0.026609 \\
(0.13815) \\
{[0.19261]}\end{array}$ & $\begin{array}{c}0.011571 \\
(0.21678) \\
{[0.05338]}\end{array}$ & $\begin{array}{r}-0.236945 \\
(0.18350) \\
{[-1.29127]}\end{array}$ \\
\hline $\mathrm{C}$ & $\begin{array}{r}-85.27211 \\
(25.8774) \\
{[-3.29523]}\end{array}$ & $\begin{array}{c}0.895378 \\
(0.85167) \\
{[1.05132]}\end{array}$ & $\begin{array}{c}2.836303 \\
(1.33643) \\
{[2.12230]}\end{array}$ & $\begin{array}{r}1.358400 \\
(1.13125) \\
{[1.20080]}\end{array}$ \\
\hline R-squared & 0.827928 & 0.947131 & 0.993760 & 0.996972 \\
\hline Adj. R-squared & 0.780460 & 0.932546 & 0.992038 & 0.996137 \\
\hline Sum sq. resids & 417.0395 & 0.451731 & 1.112310 & 0.796985 \\
\hline S.E. equation & 3.792186 & 0.124808 & 0.195846 & 0.165778 \\
\hline F-statistic & 17.44181 & 64.94005 & 577.2808 & 1193.638 \\
\hline Log likelihood & -99.43597 & 30.29316 & 13.17214 & 19.50595 \\
\hline Akaike AIC & 5.707156 & -1.120693 & -0.219586 & -0.552945 \\
\hline Schwarz SC & 6.095005 & -0.732843 & 0.168263 & -0.165095 \\
\hline Mean dependent & 11.69474 & 3.389593 & 6.397131 & 6.648649 \\
\hline S.D. dependent & 8.093439 & 0.480548 & 2.194880 & 2.667258 \\
\hline
\end{tabular}




\section{Model III}

Table VI: Vector Error Correction Estimates

\begin{tabular}{|c|c|c|c|c|c|c|}
\hline Cointegrating Eq: & CointEq1 & & & & & \\
\hline $\operatorname{INF}(-1)$ & 1.000000 & & & & & \\
\hline $\operatorname{LAGR}(-1)$ & $\begin{array}{r}-173.1351 \\
(90.7787) \\
{[-1.90722]}\end{array}$ & & & & & \\
\hline LMANQ(-1) & $\begin{array}{c}32.00217 \\
(76.2059) \\
{[0.41994]}\end{array}$ & & & & & \\
\hline $\operatorname{LCON}(-1)$ & $\begin{array}{c}-162.2566 \\
(60.0198) \\
{[-2.70339]}\end{array}$ & & & & & \\
\hline $\operatorname{LMS}(-1)$ & $\begin{array}{c}128.7728 \\
(84.4435) \\
{[1.52496]}\end{array}$ & & & & & \\
\hline $\operatorname{LEXR}(-1)$ & $\begin{array}{c}231.4148 \\
(54.3439) \\
{[4.25834]}\end{array}$ & & & & & \\
\hline $\mathrm{C}$ & 582.3647 & & & & & \\
\hline Error Correction: & $\mathrm{D}(\mathrm{INF})$ & $\mathrm{D}(\mathrm{LAGR})$ & D(LMANQ) & $\mathrm{D}(\mathrm{LCON})$ & $\mathrm{D}(\mathrm{LMS})$ & D(LEXR) \\
\hline CointEq1 & $\begin{array}{c}-0.075160 \\
(0.03153) \\
{[-2.38358]}\end{array}$ & $\begin{array}{c}0.000832 \\
(0.00028) \\
{[2.93090]}\end{array}$ & $\begin{array}{c}6.94 \mathrm{E}-06 \\
(0.00030) \\
{[0.02285]}\end{array}$ & $\begin{array}{c}0.002063 \\
(0.00067) \\
{[3.09969]}\end{array}$ & $\begin{array}{c}-4.96 \mathrm{E}-06 \\
(0.00026) \\
{[-0.01874]}\end{array}$ & $\begin{array}{c}0.001098 \\
(0.00083) \\
{[1.31903]}\end{array}$ \\
\hline $\mathrm{D}(\operatorname{INF}(-1))$ & $\begin{array}{c}-0.146576 \\
(0.16899) \\
{[-0.86735]}\end{array}$ & $\begin{array}{c}0.002274 \\
(0.00152) \\
{[1.49428]}\end{array}$ & $\begin{array}{r}-0.000946 \\
(0.00163) \\
{[-0.58117]}\end{array}$ & $\begin{array}{r}-0.000212 \\
(0.00357) \\
{[-0.05948]}\end{array}$ & $\begin{array}{r}-0.002669 \\
(0.00142) \\
{[-1.88128]}\end{array}$ & $\begin{array}{c}0.003622 \\
(0.00446) \\
{[0.81172]}\end{array}$ \\
\hline $\mathrm{D}(\mathrm{INF}(-2))$ & $\begin{array}{r}-0.578233 \\
(0.17404) \\
{[-3.32240]}\end{array}$ & $\begin{array}{r}-0.000267 \\
(0.00157) \\
{[-0.17047]}\end{array}$ & $\begin{array}{c}0.001320 \\
(0.00168) \\
{[0.78734]}\end{array}$ & $\begin{array}{r}-0.003150 \\
(0.00367) \\
{[-0.85760]}\end{array}$ & $\begin{array}{r}-0.002660 \\
(0.00146) \\
{[-1.82046]}\end{array}$ & $\begin{array}{r}-0.006564 \\
(0.00460) \\
{[-1.42840]}\end{array}$ \\
\hline $\mathrm{D}(\operatorname{LAGR}(-1))$ & $\begin{array}{c}24.19718 \\
(19.1026) \\
{[1.26669]}\end{array}$ & $\begin{array}{c}-0.008738 \\
(0.17205) \\
{[-0.05079]}\end{array}$ & $\begin{array}{c}0.248389 \\
(0.18399) \\
{[1.35000]}\end{array}$ & $\begin{array}{r}-0.064726 \\
(0.40319) \\
{[-0.16054]}\end{array}$ & $\begin{array}{c}0.139436 \\
(0.16036) \\
{[0.86949]}\end{array}$ & $\begin{array}{c}0.057998 \\
(0.50436) \\
{[0.11499]}\end{array}$ \\
\hline $\mathrm{D}(\operatorname{LAGR}(-2))$ & $\begin{array}{r}-3.634807 \\
(17.1537) \\
{[-0.21190]}\end{array}$ & $\begin{array}{r}-0.356780 \\
(0.15449) \\
{[-2.30934]}\end{array}$ & $\begin{array}{r}-0.052271 \\
(0.16522) \\
{[-0.31638]}\end{array}$ & $\begin{array}{c}-0.364294 \\
(0.36205) \\
{[-1.00619]}\end{array}$ & $\begin{array}{c}-0.256501 \\
(0.14400) \\
{[-1.78122]}\end{array}$ & $\begin{array}{r}-0.008310 \\
(0.45290) \\
{[-0.01835]}\end{array}$ \\
\hline D(LMANQ(-1)) & $\begin{array}{c}10.09886 \\
(20.6770) \\
{[0.48841]}\end{array}$ & $\begin{array}{c}0.038586 \\
(0.18623) \\
{[0.20720]}\end{array}$ & $\begin{array}{c}0.313846 \\
(0.19916) \\
{[1.57588]}\end{array}$ & $\begin{array}{r}-0.889253 \\
(0.43642) \\
{[-2.03762]}\end{array}$ & $\begin{array}{c}0.047476 \\
(0.17358) \\
{[0.27351]}\end{array}$ & $\begin{array}{r}-0.238778 \\
(0.54593) \\
{[-0.43738]}\end{array}$ \\
\hline
\end{tabular}




\begin{tabular}{|c|c|c|c|c|c|c|}
\hline D(LMANQ $(-2))$ & $\begin{array}{r}-7.429210 \\
(22.9369) \\
{[-0.32390]}\end{array}$ & $\begin{array}{c}0.263280 \\
(0.20658) \\
{[1.27447]}\end{array}$ & $\begin{array}{r}-0.017197 \\
(0.22092) \\
{[-0.07784]}\end{array}$ & $\begin{array}{r}-0.209631 \\
(0.48411) \\
{[-0.43302]}\end{array}$ & $\begin{array}{c}0.152570 \\
(0.19255) \\
{[0.79236]}\end{array}$ & $\begin{array}{r}-0.536936 \\
(0.60559) \\
{[-0.88663]}\end{array}$ \\
\hline $\mathrm{D}(\operatorname{LCON}(-1))$ & $\begin{array}{r}-9.842424 \\
(13.2065) \\
{[-0.74527]}\end{array}$ & $\begin{array}{c}0.081991 \\
(0.11894) \\
{[0.68932]}\end{array}$ & $\begin{array}{r}-0.094562 \\
(0.12720) \\
{[-0.74340]}\end{array}$ & $\begin{array}{r}-0.294188 \\
(0.27874) \\
{[-1.05541]}\end{array}$ & $\begin{array}{c}0.104850 \\
(0.11087) \\
{[0.94573]}\end{array}$ & $\begin{array}{c}-0.202962 \\
(0.34869) \\
{[-0.58208]}\end{array}$ \\
\hline $\mathrm{D}(\operatorname{LCON}(-2))$ & $\begin{array}{r}-27.27855 \\
(11.7953) \\
{[-2.31266]}\end{array}$ & $\begin{array}{r}-0.177564 \\
(0.10623) \\
{[-1.67144]}\end{array}$ & $\begin{array}{r}-0.290560 \\
(0.11361) \\
{[-2.55754]}\end{array}$ & $\begin{array}{c}0.143990 \\
(0.24896) \\
{[0.57837]}\end{array}$ & $\begin{array}{r}-0.040991 \\
(0.09902) \\
{[-0.41396]}\end{array}$ & $\begin{array}{r}0.119439 \\
(0.31143) \\
{[0.38352]}\end{array}$ \\
\hline $\mathrm{D}(\operatorname{LMS}(-1))$ & $\begin{array}{c}53.08108 \\
(23.9970) \\
{[2.21199]}\end{array}$ & $\begin{array}{c}0.283871 \\
(0.21613) \\
{[1.31344]}\end{array}$ & $\begin{array}{l}0.369225 \\
(0.23113) \\
{[1.59746]}\end{array}$ & $\begin{array}{r}-0.330956 \\
(0.50649) \\
{[-0.65343]}\end{array}$ & $\begin{array}{c}0.334999 \\
(0.20145) \\
{[1.66292]}\end{array}$ & $\begin{array}{r}-0.605373 \\
(0.63358) \\
{[-0.95548]}\end{array}$ \\
\hline $\mathrm{D}(\operatorname{LMS}(-2))$ & $\begin{array}{c}7.915541 \\
(22.9448) \\
{[0.34498]}\end{array}$ & $\begin{array}{c}0.003107 \\
(0.20665) \\
{[0.01504]}\end{array}$ & $\begin{array}{r}-0.187368 \\
(0.22100) \\
{[-0.84783]}\end{array}$ & $\begin{array}{r}-0.347577 \\
(0.48428) \\
{[-0.71772]}\end{array}$ & $\begin{array}{c}0.249576 \\
(0.19262) \\
{[1.29570]}\end{array}$ & $\begin{array}{r}-0.294728 \\
(0.60580) \\
{[-0.48651]}\end{array}$ \\
\hline $\mathrm{D}(\operatorname{LEXR}(-1))$ & $\begin{array}{c}29.90529 \\
(13.4219) \\
{[2.22810]}\end{array}$ & $\begin{array}{r}-0.150021 \\
(0.12088) \\
{[-1.24103]}\end{array}$ & $\begin{array}{c}0.104198 \\
(0.12928) \\
{[0.80601]}\end{array}$ & $\begin{array}{c}-0.256049 \\
(0.28329) \\
{[-0.90385]}\end{array}$ & $\begin{array}{c}0.024574 \\
(0.11268) \\
{[0.21810]}\end{array}$ & $\begin{array}{c}0.065225 \\
(0.35437) \\
{[0.18406]}\end{array}$ \\
\hline $\mathrm{D}(\operatorname{LEXR}(-2))$ & $\begin{array}{c}42.38710 \\
(12.2944) \\
{[3.44768]}\end{array}$ & $\begin{array}{c}0.076779 \\
(0.11073) \\
{[0.69339]}\end{array}$ & $\begin{array}{c}0.232688 \\
(0.11842) \\
{[1.96500]}\end{array}$ & $\begin{array}{r}-0.406164 \\
(0.25949) \\
{[-1.56524]}\end{array}$ & $\begin{array}{c}0.167185 \\
(0.10321) \\
{[1.61985]}\end{array}$ & $\begin{array}{r}-0.289400 \\
(0.32460) \\
{[-0.89155]}\end{array}$ \\
\hline $\mathrm{C}$ & $\begin{array}{r}-20.26785 \\
(9.36918) \\
{[-2.16325]}\end{array}$ & $\begin{array}{c}0.198995 \\
(0.08438) \\
{[2.35823]}\end{array}$ & $\begin{array}{c}0.084704 \\
(0.09024) \\
{[0.93863]}\end{array}$ & $\begin{array}{c}0.796912 \\
(0.19775) \\
{[4.02990]}\end{array}$ & $\begin{array}{c}0.030548 \\
(0.07865) \\
{[0.38839]}\end{array}$ & $\begin{array}{l}0.526779 \\
(0.24737) \\
{[2.12951]}\end{array}$ \\
\hline R-squared & 0.608185 & 0.717200 & 0.538946 & 0.486352 & 0.563395 & 0.287713 \\
\hline Adj. R-squared & 0.386725 & 0.557357 & 0.278350 & 0.196030 & 0.316619 & -0.114885 \\
\hline Sum sq. resids & 3179.215 & 0.257887 & 0.294937 & 1.416279 & 0.224053 & 2.216222 \\
\hline S.E. equation & 11.75699 & 0.105889 & 0.113240 & 0.248148 & 0.098699 & 0.310415 \\
\hline F-statistic & 2.746247 & 4.486890 & 2.068128 & 1.675214 & 2.283018 & 0.714641 \\
\hline Log likelihood & -134.8900 & 39.37305 & 36.88962 & 7.862651 & 41.97491 & -0.421114 \\
\hline Akaike AIC & 8.048106 & -1.371516 & -1.237277 & 0.331749 & -1.512157 & 0.779520 \\
\hline Schwarz SC & 8.657642 & -0.761980 & -0.627740 & 0.941285 & -0.902621 & 1.389056 \\
\hline Mean dependent & -0.269251 & 0.198800 & 0.172131 & 0.241205 & 0.207153 & 0.168634 \\
\hline S.D. dependent & 15.01303 & 0.159156 & 0.133302 & 0.276752 & 0.119393 & 0.293987 \\
\hline
\end{tabular}

Table VIII: Post Estimation Test

Model I: Breusch-Godfrey Serial Correlation LM Test:

\begin{tabular}{lrll}
\hline \hline F-statistic & 0.872335 & Prob. F(1,34) & 0.3569 \\
Obs*R-squared & 0.975589 & Prob. Chi-Square(1) & 0.3233 \\
\hline \hline Model II: Breusch-Godfrey Serial Correlation LM Test: & \\
\hline \hline F-statistic & 0.742431 & Prob. F(2,27) & 0.4854
\end{tabular}


Obs*R-squared

Model II: Breusch-Godfrey Serial Correlation LM Test:

\begin{tabular}{llll}
\hline \hline F-statistic & 0.342323 & Prob. $\mathrm{F}(2,21)$ & 0.7140 \\
Obs*R-squared & 1.168196 & Prob. Chi-Square(2) & 0.5576 \\
\hline
\end{tabular}

